\title{
Genetic Analysis for Yield and Some Yield Traits in Spring Wheat
}

\author{
Sadia Kaukab", Muhammad Sajjad Saeed, Aziz ur Rehman \\ Ayyub Agricultural Research Institute, Faisalabad, Pakistan \\ *Corresponding author: kaukabsadia@yahoo.com
}

Copyright $(2014$ Horizon Research Publishing All rights reserved.

\begin{abstract}
A $5 \times 5$ diallel cross involving five wheat varieties/lines (Kohistan-97, Chakwal-86, 6529-11, 6544-6 and 7086-1) was conducted. Twenty hybrids along with five parents were planted in randomized complete block design with three replications in order to find out the gene action controlling some vital polygenic yield related attributes like plant height, spike length, peduncle length, number of tillers per plant and grain yield per plant. Highly significant differences among genotypes were observed for all traits. Plant height has only significant differences. The graphical presentation demonstrated that number of tillers per plant was ruled by partial dominance with additive type of gene action. While over-dominance was observed in plant height, spike length, peduncle length and grain yield per plant. It showed the potential for the availability of transgressive segregates in later filial generations. The prevalence of partial dominance type of gene action for number of tillers per plant showed that it can be gradually improved by selection.
\end{abstract}

Keywords Triticum Aestivum, Cultivars, Agronomic Characters, Pakistan

\section{Introduction}

Wheat (Triticum aestivum L.) is the world's most widely adapted crop, supplying one third of the world population with more than half of their calories and nearly half of their protein. Pakistan's economy primarily depends on agriculture sector where wheat plays a pivotal role. This crop has always been a focus of research for genetic improvement but there has been a little improvement in genetics potential for yield improvement since green revolution. Yield is one of the most complex and economically important characters. So the information on genetic control of yield and yield components is more helpful for future breeding programme. The gene action can be studied through the diallel crossing technique developed by earlier scientists Hayman., [7], [8] and Jinks., [13], [14] .This breeding methodology is still considered as an important tool to work out the genetic basis for the control of traits. Over-dominance type of gene action has been reported for plant height also observed by Kashif et al.,[16], Akram et al., [1], Iqbal ., [13], Hafeez., [6], Haidari et al., [9], Saleem et al., [22], Nazeer., [20], Uma and Sharma., [25], Gurmani et al., [5] and Nazan ., [19], Over-dominance type of gene action for spike length was reported by Bakash et al., [3], Munis., [18] ,Farooq., [4], Nazeer., [20] and Inamullah et al., [12] ,Over-dominance type of gene action for number of tillers per plant was observed by Khaliq and Chowdary ., [17], Akram et al., [1], Hafeez., [6], Ullah et al ., [24], Bakhsh., [3], Farooq., [4], Nazeer., [20], Inamullah et al., [11], Inamullah et al., [12] and Gurmani et al., [5] and for grain yield was observed by Khaliq and Chowdary., [17], Bakash et al., [3], Kashif et al., [16], Munis ., [18], Akram et al., [1], Saleem et al., [22], Gurmani et al., [5], Iqbal ., [13], Farooq., [4], Inamullah et al., [11], Hafeez., [6], Haidari et al., [9], Omara et al.,[22], Inamullah et al., [12] and Nazan., [19].Others studies reported partial dominance with additive type of gene action for peduncle length that was also observed by Munis., [18], Ullah et al., [24], Uma and Sharma., [25], Hafeez., [6] and Farooq., [4].The present study was conducted to draw information about genetic mechanism controlling some important characters which could help devise future breeding strategy to evolve high yielding wheat genotypes.

\section{Materials and Methods}

This study was conducted during the year 2010. The material comprised five varieties/lines of spring wheat viz. Kohistan-97,Chakwal-86,6529-11, 6544-6 and 7086-1. This material was planted in the field on $18^{\text {th }}$ November, 2009 in a twin row of 5 meter length. The crosses were attempted in a diallel fashion including reciprocals. The hybrid seeds including reciprocals and parents were sown in RCBD with three replications. All the entries (20 crosses and 5 parent lines) were randomly assigned to 25 plots of each replication. Each plot consisted of single row of 5 meter length. The plant-to-plant and row-to-row distance was 15 and $30 \mathrm{~cm}$, respectively. Two seeds per hole were sown and after germination these were thinned to single seedling per site to 
ensure good plant stand. At the time of maturity, ten guarded plants from each line were taken at random and data were recorded on plant height, number of tillers per plant, peduncle length, spike length and grain yield per plant.

The data were subjected to analysis of variance and gene action was worked out for the characters showing significant differences among the genotypes

\section{Results and Discussion}

Analysis of variance Steel et al., [23] showed highly significant differences among genotypes for all the traits except plant height for which only significant differences were noted (Table 1).

\section{Plant Height}

Plant height is an important trait of wheat. Wheat cultivars genetically vary in plant height from short stature to medium and tall. Tall cultivars are more vulnerable to lodging than medium or short stature cultivars. So in breeding, wheat plant height should also consider as an important trait. Phenotypic expression of any trait is the out-come of the genotype $x$ environment interaction. The five parents included in this study varied from medium to tall stature.

Analysis of variance indicated the significant differences among the genotype. It is evidented from graphical analysis that plant height is controlled by over-dominance type of gene action as regression line intercepted the $\mathrm{Wr}$-axis below the point of origin see Fig 1, Non-allelic interactions were absent as regression line did not deviate from the unit slope. From array mean variety Chakwal- 86 was indicated the best general combiners having array mean value of $109.30 \mathrm{~cm}$ while genotype $6529-11$ was poorest performer with an array mean value of $107.07 \mathrm{~cm}$

Current results are in accordance with the findings of Kashif et al.,[16], Akram et al., [1], Iqbal ., [13], Hafeez., [6], Haidari et al., [9], Saleem et al., [22], Nazeer., [20], Uma and Sharma., [25], Gurmani et al., [5] and Nazan ., [19].

Distribution of array points indicates that variety Chakwal-86 contained maximum dominant genes for plant height as being nearest to the origin while genotype 7086-1 was present farthest from the origin indicating maximum recessive genes for plant height.

Because over-dominance type of gene action controlled this trait so selection in early generations for plant height would be difficult.

Table 1. Analysis of variance mean square for polygenic traits.

\begin{tabular}{|c|c|c|c|c|c|c|}
\hline SOV & Df & PH & PL & T/P & SL & GY/P \\
\hline Replication & 2 & $10.10^{\text {n.s }}$ & $11.48^{*}$ & $1.53^{\text {n.s }}$ & $0.78^{\text {n.s }}$ & $29.29^{\text {n.s }}$ \\
\hline Genotypes & 24 & $32.02^{*}$ & $5.63^{* *}$ & $1.32^{*}$ & $1.37^{* *}$ & $28.60^{* *}$ \\
\hline Error & 48 & 17.48 & 2.47 & 0.59 & 0.54 & 9.77 \\
\hline
\end{tabular}

$\mathrm{PH}=$ Plant height, $\mathrm{PL}=$ Peduncle length, $\mathrm{T} / \mathrm{P}=$ Number of tillers per plant, $\mathrm{SL}=$ Spike length, $\mathrm{GY} / \mathrm{P}=$ Grain yield

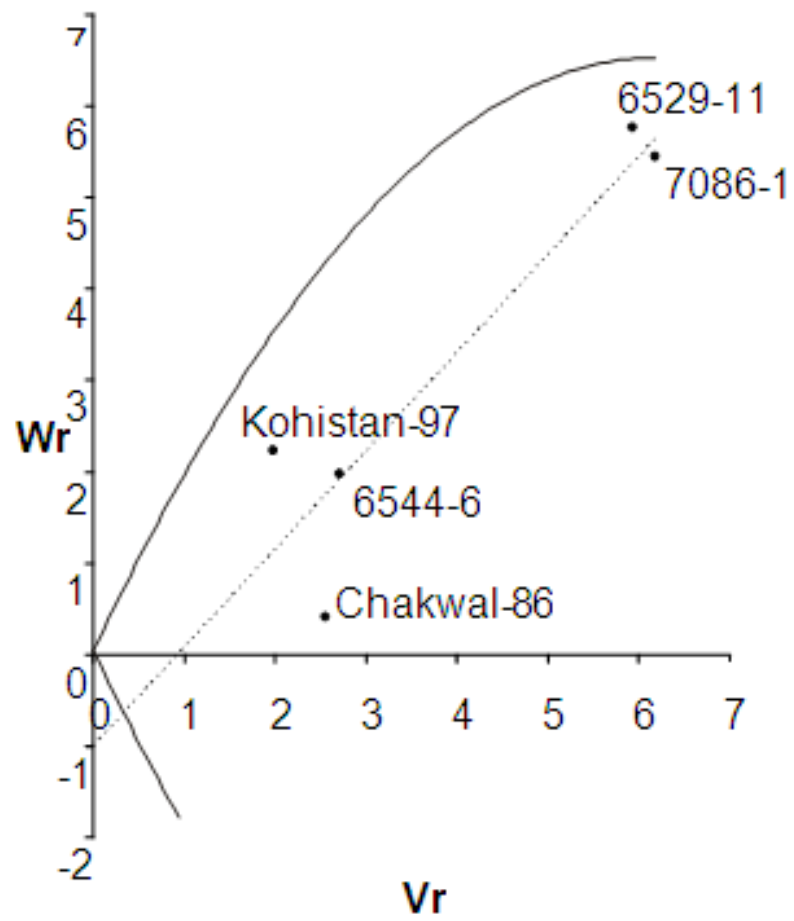

Figure 1. $\mathrm{Wr} / \mathrm{Vr}$ graph for plant height 


\section{Spike Length}

Spike length is an important yield related trait of wheat. It directly contributes to the yield. More spike length produces more spikelets per spike that ultimately produce more grains per spike thus leading to yield increase. So in wheat breeding importance should be given to this trait and spikes with more spike length should be selected.

Analysis of variance for spike length revealed highly significant differences among genotypes under study. From array mean, genotype 6529-11 was indicated the best general combiners having array means value of $13.79 \mathrm{~cm}$ while genotype 6544-6 was poorest performer with array mean value of $13.04 \mathrm{~cm}$.

Graphical presentation indicated the presence of over-dominance type of gene action for this trait as regression line intercepted $\mathrm{Wr}$-axis below the origin, see Fig. 2. Epistasis is absent as regression line followed the unit slope.

Similar results have also been reported by Bakash et al., [3], Munis., [18], Farooq., [4], Nazeer., [20] and Inamullah et al., [12].

So it can be concluded from present study that selection in early segregating generations will not be possible.

\section{Peduncle Length}

Peduncle length is also an important trait in wheat. It plays an important role in plant yield during heading stage. It varies from genotype to genotype. Analysis of variance of the data showed highly significant differences among genotypes for this trait. Persual of array means revealed that genotype 6529-11 was good general combiner having an array mean value of $18.47 \mathrm{~cm}$ while variety Chakwal-86 showed poor performance having an array mean value of $17.17 \mathrm{~cm}$.

Over-dominance type of gene action is observed from graphical analysis as regression line intercepted the Wr-axis below the point of origin, see Fig. 3. Due to over-dominance type of gene action, selection for this trait in early generations is difficult. Epistasis is not present because regression line did not deviate from unit slope.

These results are in accordance with Munis., [18] Ullah et al., [24], Uma and Sharma., [25], Hafeez., [6] and Farooq., [4].It is clear from distribution of array point that genotype 6544-6 contained maximum dominant genes for this trait being nearest to the point of origin while variety Chakwal-86 had maximum recessive genes being farthest from the origin.

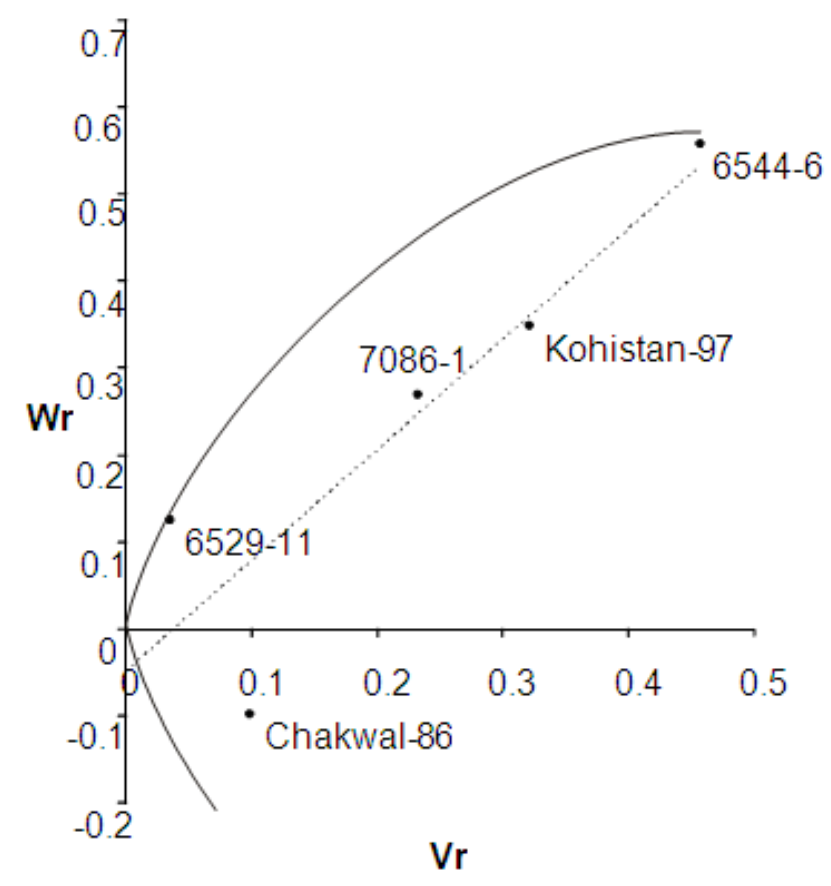

Figure 2. $\mathrm{Wr} / \mathrm{Vr}$ Graph for Spike Length 


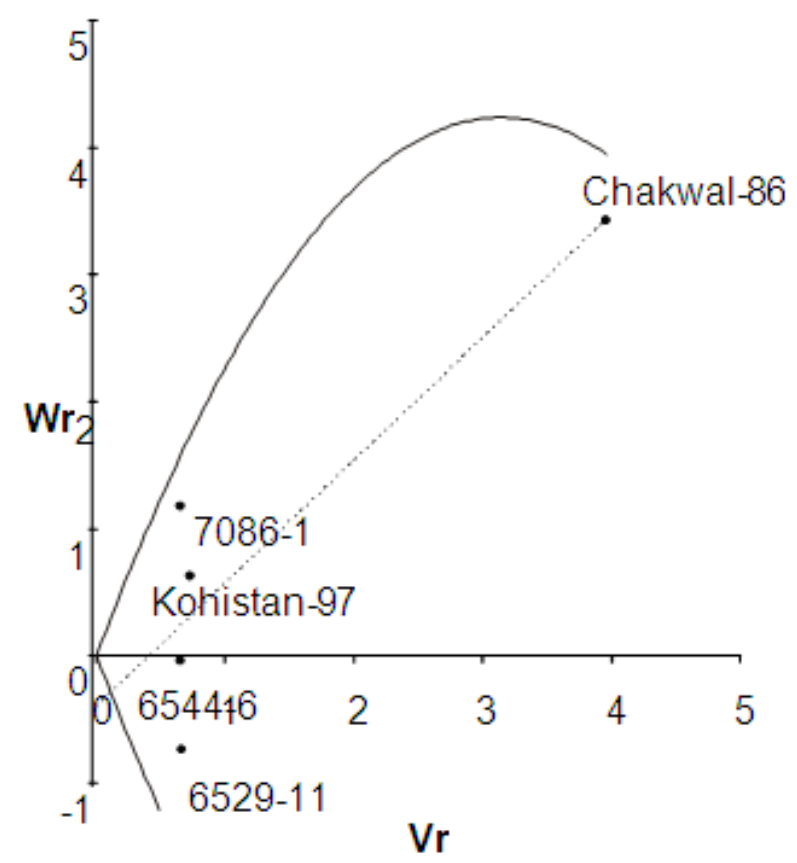

Figure 3. Wr/Vr Graph for Peduncle Length

\section{Number of Tillers per Plant}

Number of tillers per plant is a vital yield related trait. Greater number of tillers per plant ensure higher grain yield.

Analysis of variance showed highly significant differences among all genotypes. Graphical analysis for tillers per plant revealed additive types of gene action with partial dominance as $\mathrm{Wr}$-axis is touched above the point of origin by the regression. As regression line follows the unit slope so epistasis is not present. It suggests early generation selection for this trait. From array mean table it is revealed that genotype 6544-6 was good general combiners having an array mean value of $11.78 \mathrm{~cm}$ while variety $7086-1 \mathrm{had}$ poorest performance with an array mean value of $11.03 \mathrm{~cm}$

These results are also confirmed by Khaliq and Chowdary ., [17], Akram et al., [1], Inamullah et al., [11], Hafeez., [6], Ullah et al ., [24], Bakhsh., [3], Farooq., [4], Nazeer., [20], Inamullah et al., [12] and Gurmani et al., [5]. Number of tillers per plant is a vital yield related trait. Greater number of tillersper plant ensure higher grain yield. Analysis of variance showed highly significant differences among all genotypes. Graphical analysis for tillers per plant revealed additive types of gene action with partial dominance as $\mathrm{Wr}$-axis is touched above the point of origin by the regression line, see Fig 4. As regression line follows the unit slope so epistasis is not present. It suggests early generation selection for this trait. From array mean table it is revealed that genotype 6544-6 was good general combiners having an array mean value of $11.78 \mathrm{~cm}$ while variety 7086-1 had poorest performance with an array mean value of $11.03 \mathrm{~cm}$.

\section{Grain Yield per Plant}

Ultimate goal of any wheat breeding is to get maximum yield. So it is most important trait. The plant express its potential the most when it has all its needs met in right proportions and at right time.

Analysis of variance showed highly significant differences among all parental and hybrid genotypes. It was indicated that variety Kohistan-97 performed as best general combiner having highest array mean of $25.07 \mathrm{~g}$ while genotype 7086-1 was the poorest performer having array mean of $21.88 \mathrm{~g}$.

Graphical analysis indicated that regression line intercepted the Wr-axis below the point of origin, thus revealing over-dominance type of gene action, see Fig 5 . Non-allelic differences are absent as regression line did not deviate from the unit slope. 


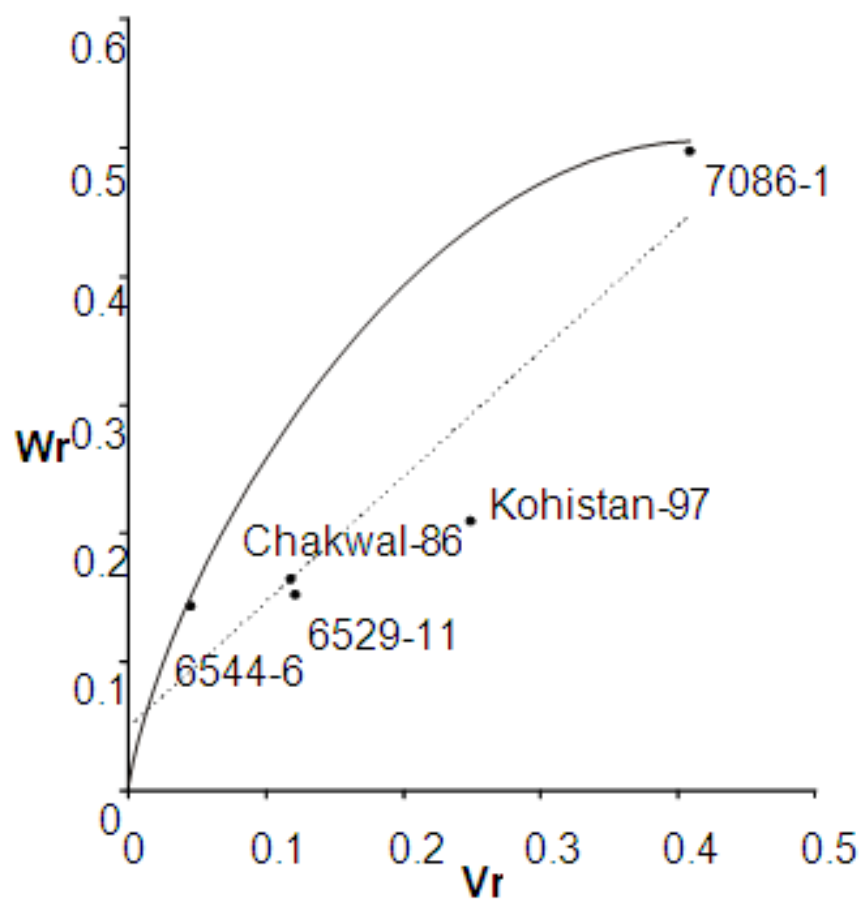

Figure 4. $\mathrm{Wr} / \mathrm{Vr}$ graph for No. of tillers/P

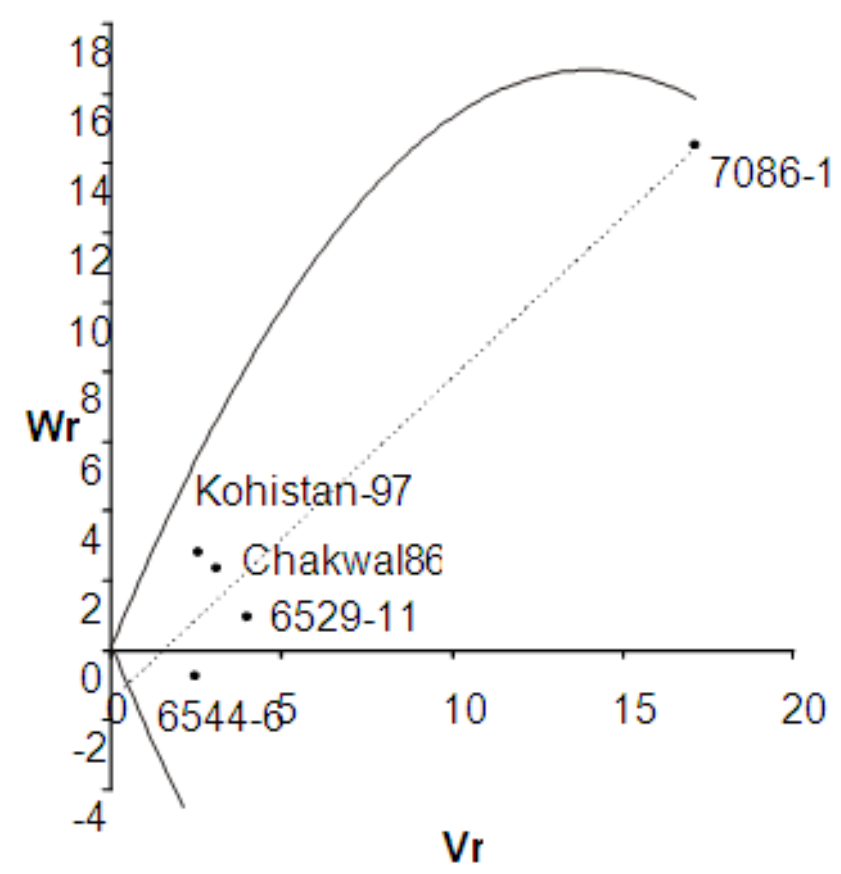

Figure 5. $\mathrm{Wr} / \mathrm{Vr}$ Graph for Grain Yield Per Plant

These results are similar to the findings of Khaliq and Chowdary., [17],Bakash et al., [3], Kashif et al., [16], Munis ., [18], Akram et al., [1], Saleem et al., [22], Gurmani et al., [5], Iqbal ., [13], Farooq., [4], Inamullah et al., [11], Hafeez., [6], Haidari et al., [9], Omara et al.,[22], Inamullah et al., [12] and Nazan., [19]. Distribution of array points along the regression line showed that genotype 6544-6 had maximum dominant genes for grain yield per plant being nearest to the point of origin while genotype 7086-1 had minimum dominant genes as its distance from the point of origin is maximum

\section{Conclusions}

The present study revealed the presence of over-dominance type of gene action for plant height, peduncle length, spike length and grain yield per plant whereas, additive type of gene action with partial dominance was found for number of tillers per plant. Transgressive 
segregates can be found for plant height, spike length, number of tillers per plant in later segregating generations. However, desirable peduncle length can be fixed by gradual selection in segregating populations.

\section{REFERENCES}

[1] Akram, Z., S.U.K. Ajma and M. Munir. 2004. Gene action study of some agronomic traits in spring wheat (Triticum aestivum L.) Pak. J. Arid Agric. 7(2): 39-43.

[2] Anonymous. 2011-12. Economic Survey of Pakistan. Ministry of Food, Agriculture and Livestock, Economic Advisor Wing, Islamabad, Pakistan.

[3] Bakhsh, A., A. Hussain and A.S. Khan. 2003. Genetic studies of plant height, yield and its components in bread wheat. Sarhad J. Agric. 19(4): 529-534.

[4] Farooq, A.B.U. 2005. Inheritance study of various morphological traits in spring wheat (Triticum aestivum L.). M.Sc (Hons) Agri. Thesis, Deptt. P1. Br. Genet., Univ. Agri. Faisalabad, Pakistan.

[5] Gurmani, R.R., S.J. Khan, Z.A. Saqib, R. Khan, A. Shakeel and Mohib ullah. 2007. Genetic evaluation of some yield and yield related traits in wheat. Pak. J. Agri. Sci. 44(1): 6-10.

[6] Hafeez, Z. 2006. A biometrical analysis of some metric traits in a 5 x 5 diallel cross of bread wheat. M.Sc. (Hons) Agri. Thesis, Deptt. P1. Br. Genet., Univ. of Agri. Faisalabad, Pakistan.

[7] Hayman, B. I. 1954a. The theory and analysis of diallel crosses. Genetics, 39: 789-809.

[8] Hayman, B. I. 1954b. The theory and analysis of diallel crosses. Biometrics 10: 235-245.

[9] Heidari, B., A. Rezai and S.A.M. Mirmohammadi Maibody. 2006. Diallel analysis for the estimation of genetic parameters for grain yield and grain yield components in bread wheat. J. Sci. and Technol. Agric. and Natur. Resour. 10(2): 140-143.

[10] Heyne, E.G. 1987. Wheat and Wheat Improvement. 2nd edition. Madison, Wiscon, USA: 32-40.

[11] Inamullah, F. Muhammad and G. Hassan. 2005. Genetics of important traits in bread wheat using diallel analysis. Sarhad J. Agric. 21(4): 617-622.

[12] Inamullah, H.A., F. Muhammad, Siraj-ud-din, G. Hassan and R. Gul. 2006. Diallel analysis of the inheritance pattern of agronomic traits of bread wheat. Pak. J. Bot.
38(4):1169-1175.

[13] Iqbal, M. 2004. Diallelic analysis of some physio-morphological traits in spring wheat irrigated conditions. J. Sci. Technol. Agric. Natur. Resour. 11(1): 214-221.

[14] Jinks, J. L. 1954. The analysis of continuous variation in a diallel cross of Nicotiana rustica varieties. Genetica.39: 767-788.

[15] Jinks, J. L. 1955. A survey of the genetical basis of hetrosis in a variety of diallel crosses. Heredity. 9: 223-238.

[16] Kashif, M., J. Ahmad, M.A. Chowdhry and K. Perveen. 2003. Study of genetic architecture of some important agronomic traits in durum wheat (Triticum durum desf). Asian J. Pl. Sci. 2(9): 708-712.

[17] Khaliq, I. and M.A. Chowdhry. 2001. Inheritance of yield related traits across environments. Pak. J. Biol. Sci. 4(47): 829-837.

[18] Munis, M.F.H. 2003. Mode of gene action for some post emergence traits in spring wheat. M.Sc. (Hons) Agri. Thesis, Deptt. Pl. Br. Genet., Univ. of Agri. Faisalabad, Pakistan

[19] Nazan, D.A. 2008. Genetic analysis of grain yield per spike and some agronomic traits in diallel cross of bread wheat (Triticum aestivum L.). Turk. J. Agric. For. 32: 54-59.

[20] Nazeer, W. 2005. Genetic architecture for some metric traits in hexaploid wheat. M.Sc (Hons) Agri. Thesis, Deptt. P1. Br. Genet., Univ. of Agri. Faisalabad, Pakistan.

[21] Omara, M.K., M.M. El-Defwawy, A.M. Tamman and A.A.F. Kassem. 2004. Genetic control of preanthesis attributes of wheat plant and their associations with yield under heat stress. Assiut J. Agri. Sci. 35: 97-114.

[22] Saleem, M., M.A. Chowdhry, M. Kashif and M. Khaliq. 2005. Inheritance pattern of plant height, grain yield and some leaf characteristics of spring wheat. Int. J. Agri. Biol. 7(6): 1015-1018

[23] Steel, R.G.D., J.H. Torrie and D.A. Dickey. 1997. Principles and procedures of statistics. A biometrical approach. 3rd ed. McGraw Hill Book Co., NewYork.

[24] Ullah, S., A.S. Khan, A. Raza and S. Sadique, 2010. Gene action analysis of yield and yield related traits in spring wheat (Triticum aestivum). Int. J. Agric. Biol., 12: 125-128.

[25] Uma, M. and S.N. Sharma. 1997. Genetics of yield determining factors in spring wheat over environments. Indian J. Genet. Pl. Br. 57(3): 301-306. 